\title{
The effectiveness of functional training on static balance, dynamic balance and flexibility of female students with intellectual disability
}

Authors' Contribution: A Study Design B Data Collection C Statistical Analysis D Data Interpretation E Manuscript Preparation F Literature Search G Funds Collection

\author{
Sakineh Farrokhian ${ }^{1}$ ABCDEFG, Ghorban Hemati Alamdarloo ${ }^{1}$ ABCDEFG, \\ Enayatollah Asadmanesh ${ }^{2}$ ABCDEFG \\ ${ }^{1}$ Special Education Department, School of Education and Psychology, \\ Shiraz University, Shiraz, Iran \\ 2 Physical Education Department, School of Education and Psychology, \\ Shiraz University, Shiraz, Iran
}

\section{abstract}

Background:

Material and methods:

Results: The results showed that functional training had a significant effect on static and dynamic balance and flexibility of female students with intellectual disability $(p<0.05)$.

Conclusions: It is recommended that functional training be given special attention by educators, teachers and child education experts.

Key words: children with intellectual disability (ID) have less balance and flexibility than typically developing peers.

\section{article details}

Article statistics:

Full-text PDF:

Word count: 2,213; Tables: 4; Figures: 0; References: 36

Received: April 2020; Accepted: May 2021; Published: September 2021

Copyright

Indexation:

http://www.balticsportscience.com

(c) Gdansk University of Physical Education and Sport, Poland

Celdes, Clarivate Analytics Emerging Sources Citation Index (ESCI), CNKI Scholar (China National Knowledge Infrastructure), CNPIEC, DOAJ, EBSCO - Central \& Eastern European Academic Source, EBSCO - SPORTDiscus, EBSCO Discovery Service, Google Scholar, Index Copernicus, J-Gate, Naviga (Softweco, Primo Central (ExLibris), ProQuest - Family Health, ProQuest - Health \& Medical Complete, ProQuest - Illustrata: Health Sciences, ProQuest Nursing \& Allied Health Source, Summon (Serials Solutions/ProQuest, TDOne (TDNet), Ulrich's Periodicals Directory/ ulrichsweb, WorldCat (OCLC)

Funding: This research received no specific grant from any funding agency in the public, commercial, or not-for-profit sectors.

Conflict of interests: Authors have declared that no competing interest exists.

Corresponding author:

Ghorban Hemati Alamdarloo, Faculty of Education and Psychology, Special Education Department, Shiraz University, Eram Square, Shiraz, Iran; Phone: +98-713-6134654; Fax: +98-713-6286441; E-mail: ghemati@shirazu.ac.ir

Open Access License: This is an open access article distributed under the terms of the Creative Commons Attribution-Non-Commercial-NoDerivatives 4.0 International (https://creativecommons.org/licenses/by-nc-nd/4.0/), which permits use, distribution, and reproduction in any medium, provided the original work is properly cited, the use is non-commercial and is otherwise in compliance with the license. 


\section{INTRODUCTION}

Intellectual Disability (ID) is a disability characterized by significant limitations both in intellectual functioning (reasoning, learning, problem solving) and in adaptive behavior, which covers a range of everyday social and practical skills. This disability originates before the age of 18 [1]. Children with disability have motor weakness, which negatively affects the neuromuscular, skeletal, and sensory-motor systems [2, 3]. Moreover, children with ID have poorer physical fitness and motor performance than their peers. They have less physical activity and they are sedentary [4-8].

In this regard, Guidetti et al. [9] and Pitetti et al. [7] have shown that the performance of people with ID in strength, endurance, flexibility, motor coordination, and cardiovascular endurance is significantly weaker than in typically developing individuals. Blomqvist et al. [10] have found that children with ID have less balance and flexibility than typically developing peers. Inactivity leads to health problems, such as obesity, hypertension, back pain, coronary heart disease, diabetes, depression, anxiety, and mortality [8]. Massion [11] has shown that physical fitness and exercise are one of the most effective ways to overcome physical and psychological problems in people with disabilities. In support of this, Carter et al. [12] concluded that a vestibular stimulation-training program had a positive and significant effect on balance, coordination and agility in children with Down syndrome. Similarly, Smith et al. [13] concluded that exercise programs had a positive and significant effect on aerobic capacity, balance and agility in children with motor coordination disorder. In this regard, various studies have shown that physical activity has a positive effect on balance, strength, endurance and flexibility of people with ID [14-16].

Physical activity has many benefits including physical health and fitness, positive body image, improved quality of life, improved social skills, improved self-esteem. It also helps to relieve stress, develop friendships and maintain relationships with family and friends, and provide opportunities for community presence [17, 18].

Generally, on the one hand, physical performance of children with ID is weaker than of typically developing peers [2-8], and on the other hand, various studies have shown that physical activity has a positive and significant effect on improving physical performance of people with ID [11-16]. However, the effects of functional training (FT) on the physical performance of children with ID have received little attention. FT is a set of sports activities that are based on daily routine activities, such as walking, climbing up stairs and going down, getting up and sitting down. FT focuses on improving physical fitness, such as endurance, strength, flexibility and balance [19] as well as multilateral movement [20]. FT is effective on factors of physical fitness including balance and flexibility [21]. Balance is ability to maintain body position and its components to the outside [22]. Flexibility is range of motion in specific muscle or ability to move the muscles [23].

The effectiveness of FT on balance and flexibility of children with ID has received little attention in research. Most families of children with ID are culturally and economically poor. They cannot afford expensive treatments, such as medical, paramedical and psychological services. With this research, we want to help families prevent problems. It is necessary to study the effect of FT as a simple educational method without side effects. This study presents an available method for improving physical performance of children with ID for professionals, teachers, parents and educators. The purpose of this study was to investigate the effectiveness of FT on static and dynamic balance and flexibility in female students with ID. The authors aim to answer the following questions:

1. Does FT have a significant impact on static and dynamic balance of female students with ID?

2. Does FT have a significant impact on flexibility of female students with ID? 


\section{MATERIALS AND METHODS}

\section{POPULATION, SAMPLE, AND SAMPLING METHOD}

The research method was experimental with pre-test and post-test with a control group. The statistical population consisted of all female students with ID in elementary school of Shiraz studying under the auspices of the Special Education Organization in 2018-2019. The participants included 30 female students with ID selected through convenience sampling and randomly assigned to the experimental $(n=15)$ and control $(n=15)$ groups. Both groups had pre-test of static and dynamic balance and flexibility before the intervention program. After the intervention program, both groups had post-test of static and dynamic balance and flexibility.

\section{PROCEDURE FOR FT}

FT were implemented in 15 sessions. Each session lasted from 45 to 60 minutes. These programs were run for five weeks and three sessions per week. Each exercise was repeated 3 set and 12 to 15 times per session. The movements were performed by the instructor and the children observed and performed it. The exercises were based on FT and included:

1) Squat overhead: Participants place their hands above the head and hold a ball with two hands. While the legs are open, be in the squat mode and knees bent 90 degrees. Then stand with your hands in the same position.

2) Russian twist with a ball: Sitting on the ground, knees bent, legs together and slightly above the ground level. Put the hands in front with a ball in hands, rotate the upper back straight without lowering the legs or bending and after a second's pause, turn left and continue moving.

3) Lange: While holding two balls in the palms of your hands, put one foot ahead of the other, bend one of the knees and try to keep the waist straight. After the eight sets are over, change legs and continue with the other foot.

4) Landing on one leg from a box: jump down from the box with one foot and repeat with the other.

5) Wall push-up: This modified Swedish type of swimming is the most comfortable type of swim and is very convenient to start. Stand in front of the wall, hands on the wall and bend forward and return to the first position.

6) Kickback: Straighten and stretch the left hand and right foot, then repeat with the opposite hand and foot.

\section{INSTRUMENTS}

Static Balance measurement: Single leg stance test (Stork test) was used for measuring static balance. The subject stands on one leg and places the toes of the other leg on the knee of the first leg and tries to maintain balance without making any changes to these conditions. This test score is equal to the maximum standing time. The best score comes after three moves. If one starts to disrupt the balance, he or she will be given another chance [24].

Dynamic Balance measurement: Tandem gait test was used for measuring dynamic balance. The subject walks on a straight line with one foot in front of the other (collision of the front heel to rear leg toenails) for 60 seconds, during this time, any error, such as swinging or loss of balance, will be reduced by one second. Tandem Walking test is a relatively old and easy to do test $[25,26]$. 
Flexibility measurement: Sit \& Reach Test was used for measuring flexibility. A box and a mattress were used to assess flexibility. The subject sits on the floor with his or her knees stretched and flat, while the soles of the feet stick to the side of the box. He/she holds the hands parallel to each other and places one hand on top of the other, leaning forward from the waist area and gently pushing the hands onto the surface of the box. The hands and knees should not bend. The maximum distance the fingers touch the box is considered a record [27].

\section{ethical Cconsiderations}

Parents gave consent for participation of their children in this study. The parents were aware of the purpose of the study, and their children had the right to leave the study at any time. They were assured that all their information would remain confidential. The ethical review board of the regional Special Education Organization approved the study.

\section{RESULTS}

Table 1 shows the mean values for static balance, dynamic balance and flexibility for the experimental and control groups.

Table 1. Mean and standard deviation of static balance, dynamic balance, flexibility in the experimental and the control group

\begin{tabular}{|c|c|c|}
\hline \multirow{3}{*}{ Groups } & \multicolumn{2}{|c|}{ Descriptive statistics } \\
\hline & Pre-test & Post-test \\
\hline & $M(S D)$ & $M(S D)$ \\
\hline \multicolumn{3}{|l|}{ Static balance } \\
\hline Experimental & $10.20(5.3)$ & $14.93(6.78)$ \\
\hline Control & $9.87(4.90)$ & $10.13(4.70)$ \\
\hline \multicolumn{3}{|l|}{ Dynamic Balance } \\
\hline Experimental & $13.93(6.94)$ & $17.20(8.08)$ \\
\hline Control & $13.53(4.62)$ & $13.73(4.45)$ \\
\hline \multicolumn{3}{|l|}{ Flexibility } \\
\hline Experimental & $-0.93(7.54)$ & $1.20(7.64)$ \\
\hline Control & $-0.73(7.10)$ & $-0.60(7.21)$ \\
\hline
\end{tabular}

To determine whether changes in the mean values were statistically significant or not, analysis of covariance (ANCOVA) was run. It is worth noting that regression homogeneity and homogeneity of variance were investigated prior to the ANCOVA. The results showed that the use of the ANCOVA test was possible. The results of ANCOVA are presented in Tables 2, 3 and 4 .

Table 2. Analysis of covariance results for static balance in the experimental and the control group

\begin{tabular}{lcccccc} 
Changes & $\begin{array}{c}\text { Sum of } \\
\text { squares }\end{array}$ & $\begin{array}{c}\text { Degrees of } \\
\text { freedom }\end{array}$ & $\begin{array}{c}\text { M of sum of } \\
\text { squared }\end{array}$ & F & $\begin{array}{c}\text { significance } \\
\text { level }\end{array}$ & $\begin{array}{c}\text { Etta } \\
\text { coefficient }\end{array}$ \\
\hline Pre-test & 887.694 & 1 & 887.694 & 347.494 & 0.01 & 0.928 \\
Group & 147.317 & 1 & 147.317 & 57.668 & 0.01 & 0.681 \\
Error & 68.973 & 27 & 2.023 & & & \\
Total & 8542.000 & 30 & & & & \\
\hline
\end{tabular}

According to the pre-test scores, the difference between the students' performance in the experimental and control groups was statistically significant in the post-test of static balance $(F=57.668, P<0.01)$. The difference between the scores of the two groups of 
students indicated that the FT program had an effect on static balance, and the effect was 0.68 .

Table 3. Analysis of covariance results for dynamic balance in the experimental and the control group

\begin{tabular}{lrrrrrr} 
Changes & $\begin{array}{c}\text { Sum of } \\
\text { squares }\end{array}$ & $\begin{array}{c}\text { Degrees of } \\
\text { freedom }\end{array}$ & $\begin{array}{c}\text { M of sum of } \\
\text { squared }\end{array}$ & F & $\begin{array}{c}\text { significance } \\
\text { level }\end{array}$ & $\begin{array}{c}\text { Etta } \\
\text { coefficient }\end{array}$ \\
\hline Pre-test & 1121.124 & 1 & 1121.124 & 431.141 & 0.01 & 0.941 \\
Group & 69.120 & 1 & 69.120 & 26.581 & 0.01 & 0.496 \\
Error & 70.210 & 21 & 2.600 & & & \\
Total & 1281.468 & 30 & & & & \\
\hline
\end{tabular}

According to the pre-test scores, the difference between the students' performance in the experimental and control groups was statistically significant in the post-test of dynamic balance $(F=26.581, P<0.01)$. The difference between the scores of the two groups of students indicated that the FT program had an effect on dynamic balance, and the effect was 0.496 .

Table 4. Analysis of covariance results for flexibility in the experimental and the control group.

\begin{tabular}{lcccccc} 
Changes & $\begin{array}{c}\text { Sum of } \\
\text { squares }\end{array}$ & $\begin{array}{c}\text { Degrees of } \\
\text { freedom }\end{array}$ & $\begin{array}{c}\text { M of sum of } \\
\text { squared }\end{array}$ & F & $\begin{array}{c}\text { significance } \\
\text { level }\end{array}$ & $\begin{array}{c}\text { Etta } \\
\text { coefficient }\end{array}$ \\
\hline Pre-test & 1530.690 & 1 & 1530.690 & 1632.903 & 0.01 & 0.984 \\
Group & 30.055 & 1 & 30.055 & 32.062 & 0.01 & 0.543 \\
Error & 25.310 & 27 & 0.937 & & & \\
Total & 1580.300 & 30 & & & & \\
\hline
\end{tabular}

According to the pre-test scores, the difference between the students' performance in the experimental and control groups was statistically significant in the post-test of flexibility $(\mathrm{F}=26.581, \mathrm{P}<0.01)$. The difference between the scores of the two groups of students indicated that the FT program had an effect on flexibility, and the effect was 0.543.

\section{DISCUSSION}

The aim of this study was to investigate the effect of FT on static balance, dynamic balance and flexibility in female students with ID. The research findings showed that FT has positive and significant effects on social static balance, dynamic balance and flexibility of female students with ID. These findings are consistent with those of Gorla, Costa, Silva, Costa, \& Araujo [2], Kachouri, Borji, Baccouch, Laatar, Rebai, Sahli [28] and Lee \& Lee [29]. This was in line with the findings of Weiss et al. [30]. The results of the research by Weiss et al. [30] suggest that FT can increase balance. Kachouri et al. [28] examined the effect of combined exercise program on postural strength and balance in boys with ID. Their results showed that static balance improved after eight weeks (three times a week) of combined exercise. Gorella et al. [2] also examined the effect of physical education classes on the balance of children with ID of 6 to 11 years of age. The results showed that the balance of these children improved with participation in physical education classes. Lee and Lee [29] found in their study that high-speed squat training promotes static and dynamic balance. In explaining this result, it can be said that FT can improve balance by improving the system of proprioception in the joints and obtaining more comprehensive and qualitative information and sending it to the cerebellum [20]. FT utilizes multiple muscles to increase a person's strength and balance and effectively improve general fitness [29]. 
Another exercise was box jumping and landing on one leg (plyometric exercise), which was effective in strengthening static balance. Balance control consists of a continuous feedback system of visual, vestibular and body sensory processes as well as neuromuscular processes. Also an important component of the body sensory system is proprioception, which includes afferent information from intra-articular receptors, muscles and tendons which is enhanced through physical training and increased balance [31]. In addition, balance is a multifactorial issue that is influenced by various factors such as strength, proprioception, reaction speed, and motor coordination. Functional exercises have the potential to improve these factors simultaneously [32].

Findings showed that FT improves flexibility of female students with ID. Weiss et al. [30] found similar results in their studies. They found that a combination of multi-joint exercises, especially those involving the hip and moving in multiple directions, could increase flexibility. Kloubec [33] showed that 12 weeks of Pilates training could significantly increase hamstring flexibility. In explaining this finding, it can be said that stretching improves flexibility. A variety of tensile techniques (static and ballistic) show a significant increase in the range of motion [34]. If participants maintain a stretch of 30 to 60 seconds, they will have the most flexibility [33].

The neurophysiological properties cause the contractile tissues to respond to stretching exercise. In stretching exercises, slow stretching activates soft tissues (skin, tendons and joints) and muscles of the Golgi tendon. This sensory receptor detects the difference in stress caused by passive stretching or contraction of the active muscle. The Golgi tendon organ inhibits alpha motoneuron activity [35].

According to the stress pressure curve, when gentle force is applied perpendicularly to the cross-sectional area of the tissue, the collagen fibers become smooth. At extra pressure, the recyclable deformation occurs in the elastic range. This change releases heat and prolongs the muscle [36].

\section{CONCLUSION}

The results showed that FT improved static and dynamic balance and flexibility in female students with ID. FT increases physical ability and relieves motor problems in female students with ID. Therefore, parents, psychologists, educators, teachers, and people who work with female students with ID can help these people with functional exercises.

\section{ACKNOWLEDGMENTS}

We would like to thank the management and all the colleagues of Ehsan School for female students with ID for their cooperation in conducting this research. Thanks to the parents and students who participated in this project. We hope that the findings of this study can help improve physical performance and improve the quality of life of children with ID.

\section{REFERENCES}

[1] Schalock RL, Borthwick-Duffy SA, Bradley VJ, et al. Intellectual disability: Definition, classification, and systems of supports. American Association on Intellectual and Developmental Disabilities. 444 North Capitol Street NW Suite 846, Washington, DC 20001; 2010.

[2] Gorla JI, Leonardo TC, Paulo FA. Performance of balance beam task of KTK by people with intellectual disability. J of Artigo. 2010;8:101.

[3] Horvat M, Franklin C. The effects of the environment on physical activity patterns of children with ID. Res Q Exerc Sport. 2001;72(2):189-95. https://doi.org/10.1080/02701367.2001.10608949

[4] Skowroński W, Horvat M, Nocera J, Roswal G, Croce R. Eurofit special: European fitness battery score variation among individuals with intellectual disabilities. Adapt Phys Activ Q. 2009;26(1):54-67. https://doi.org/10.1123/apaq.26.1.54 
[5] Frey GC, Stanish HI, Temple VA. Physical activity of youth with intellectual disability: review and research agenda. Adapt Phys Activ Q. 2008;25(2):95-117.

[6] Hands B, Larkin D. Physical fitness differences in children with and without motor learning difficulties. Eur J Spec Needs Educ. 2006;21(4):447-56. https://doi.org/10.1080/08856250600956410

[7] Pitetti KH, Yarmer DA, Fernhall B. Cardiovascular fitness and body composition of youth with and without mental retardation. Adapt Phys Activ Q. 2001;18(2):127-41.

[8] Beange H, Lennox N, Parmenter TR. Health targets for people with an intellectual disability. J Intellect Develop Disabil. 1999;24(4):283-97. https://doi.org/10.1080/13668259900034051

[9] Guidetti L, Franciosi E, Gallotta MC, Emerenziani GP, Baldari C. Could sport specialization influence fitness and health of adults with mental retardation? Res Develop Disabil. 2010;31(5):1070-5. https://doi.org/10.1016/j.ridd.2010.04.002

[10] Blomqvist S, Olsson J, Wallin L, Wester A, Rehn B. Adolescents with intellectual disability have reduced postural balance and muscle performance in trunk and lower limbs compared to peers without intellectual disability. Res Develop Disabil. 2013;34(1):198-206. https://doi.org/10.1016/j.ridd.2012.07.008

[11] Massion J. Sport et autism. Sci Sport. 2006;21(4):243-8. https://doi.org/10.1016/j.scispo.2006.07.001

[12] Carter K, Sunderman S, Burnett SW. The effect of vestibular stimulation exercises on balance, coordination, and agility in children with Down syndrome. Ame J Psychiatr Neurosci. 2018;6(2):28-32. https://doi.org/10.11648/j. ajpn.20180602.11

[13] Smits-Engelsman BC, Jelsma LD, Ferguson GD. The effect of exergames on functional strength, anaerobic fitness, balance and agility in children with and without motor coordination difficulties living in low-income communities. Human Mov Sci. 2017;55:327-37. https://doi.org/10.1016/j.humov.2016.07.006

[14] Wu CL, Lin JD, Hu J, Yen CF, Yen CT, Chou YL, Wu PH. The effectiveness of healthy physical fitness programs on people with intellectual disabilities living in a disability institution: six-month short-term effect. Res Develop Disabil. 2010;31(3):713-7. https://doi.org/10.1016/j.ridd.2010.01.013

[15] Carmeli E, Barak S, Morad M, Kodesh E. Physical exercises can reduce anxiety and improve quality of life among adults with intellectual disability. Int Sport Med J. 2009;10(2):77-85.

[16] Pommering TL, Brose JA, Randolph E, Murray TF, Purdy RW, Cadamagnani PE, Foglesong JE. Effects of an Aerobic Exercise Program on Community-Based Adults with Mental Retardation ["Accepted by Louis Rowitz"]. Mental Retard. 1994;32(3):218.

[17] Laskowski ER, The role of exercise in the treatment of obesity. PubMed R. 2012;4(11):840-844. https://doi. org/10.1016/j.pmrj.2012.09.576

[18] Hassan D, Dowling S, McConkey R, editors. Sport, coaching and intellectual disability. Routledge; 2014. https://doi. org/10.4324/9781315818726

[19] King MB, Judge JO, Whipple R, Wolfson L. Reliability and responsiveness of two physical performance measures examined in the context of a functional training intervention. Phys Ther. 2000;80(1):8-16. https://doi.org/10.1093/ $\mathrm{ptj} / 80.1 .8$

[20] Boyle M. New functional training for sports. Human Kinetics; 2016.

[21] Shangold MM, Mirkin G. The complete sports medicine book for women. New York: Simon \& Schuster; 1985.

[22] Hartman E, Houwen S, Scherder E, Visscher C. On the relationship between motor performance and executive functioning in children with intellectual disabilities. J Intellect Disabil Res. 2010;54(5):468-77. https://doi.org/10.1111/ j.1365-2788.2010.01284.x

[23] Kemmochi M, Sasaki S, Ichimura S. Association between reduced trunk flexibility in children and lumbar stress fractures. J Orthop. 2018;15(1):122-7. https://doi.org/10.1016/j.jor.2018.01.014

[24] Bird ML, Hill KD, Fell JW. A randomized controlled study investigating static and dynamic balance in older adults after training with Pilates. Arch Phys Med Rehabil. 2012;93(1):43-9. https://doi.org/10.1016/j.apmr.2011.08.005

[25] Cohen HS, Stitz J, Sangi-Haghpeykar H, Williams SP, Mulavara AP, Peters BT, Bloomberg JJ. Tandem walking as a quick screening test for vestibular disorders. Laryngoscope. 2018;128(7):1687-91. https://doi.org/10.1002/lary.27022

[26] Howell DR, Brilliant AN, Meehan III WP. Tandem gait test-retest reliability among healthy child and adolescent athletes. J Athlet Training 2019;54(12):1254-9. https://doi.org/10.4085/1062-6050-525-18

[27] Kaur J, Ganer N, Malik M, Kenkerwal G. Correlation of sit and reach test and indirect inclinometer measurement of hip joint angle in hamstring flexibility testing in Indian school going girls and boys. Roman J Phys Ther/Revista Romana de Kinetoterapie. 2015;21(35):48-55.

[28] Kachouri H, Borji R, Baccouch R, Laatar R, Rebai H, Sahli S. The effect of a combined strength and proprioceptive training on muscle strength and postural balance in boys with intellectual disability: An exploratory study. Res Deveop Disabil. 2016;53:367-76. https://doi.org/10.1016/j.ridd.2016.03.003

[29] Lee JY, Lee DY. Effect of different speeds and ground environment of squat exercises on lower limb muscle activation and balance ability. Technol Health Care. 2018;26(4):593-603. https://doi.org/10.3233/THC-181201

[30] Weiss T, Kreitinger J, Wilde H, Wiora C, Steege M, Dalleck L, Janot J. Effect of functional resistance training on muscular fitness outcomes in young adults. J Exerc Sci Fitness. 2010; 8(2):113-22. https://doi.org/10.1016/S1728869X(10)60017-2

[31] Goodway JD, Ozmun JC, Gallahue DL. Understanding motor development: Infants, children, adolescents, adults. Jones \& Bartlett Learning; 2019.

[32] Gaedtke A, Morat T. TRX suspension training: A new functional training approach for older adults-development training control and feasibility. Int J Exerc Sci. 2015;8(3):224. https:/pubmed.ncbi.nlm.nih.gov/27182415/

[33] Kloubec JA. Pilates for improvement of muscle endurance, flexibility, balance, and posture. J Strength Cond Res. 2010; 24(3):661-7. https://doi.org/10.1519/JSC.0b013e3181c277a6

[34] Decoster LC, Cleland J, Altieri C, Russell P. The effects of hamstring stretching on range of motion: a systematic literature review. J Orthop Sport Phys Ther. 2005; 35(6): 377-87. https://doi.org/10.2519/jospt.2005.35.6.377 
Farrokhian S, Hemati Alamdarloo G, Asadmanesh E.

Functional training vs static balance, dynamic balance and flexibility in intelectually disabled females

Balt J Health Phys Act. 2021;13(3):63-70

[35] McArdle WD, Katch FI, Katch VL. Exercise physiology: nutrition, energy, and human performance. Lippincott Williams \& Wilkins; 2010.

[36] Phrompaet S, Paungmali A, Pirunsan U, Sitilertpisan P. Effects of Pilates training on lumbo-pelvic stability and flexibility. Asian J Sport Med. 2011;2(1):16. https://doi.org/10.5812/asjsm.34822

Cite this article as:

Farrokhian S, Hemati Alamdarloo G, Asadmanesh H.

The effectiveness of functional training on static balance, dynamic balance and flexibility of female students with intellectual disability

Balt J Health Phys Act. 2021;13(3):63-70

doi: 10.29359/BJHPA.13.3.08 